\title{
The Unicity of Orthodox Spirituality
}

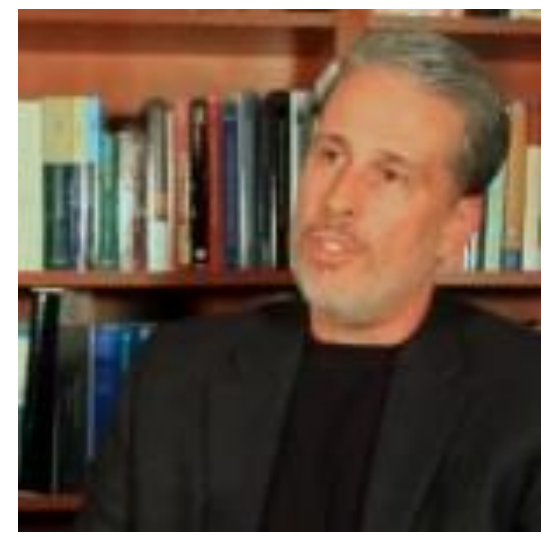

Rico Vitz is Professor and Chair of the Department of Philosophy at Azusa Pacific University, and serves as the Executive Vice President-Treasurer of the Hume Society. He is the author of Reforming the Art of Living: Nature Virtue and Religion in Descartes's Epistemology (Springer), and the editor of The Ethics of Belief (Oxford) and of Turning East: Contemporary Philosophers and the Ancient Christian Faith (St Vladimir's Seminary Press). He is a member of St. Peter the Apostle Antiochian Orthodox Christian Church in Pomona, California, U.S.A.

Tudor Petcu: At the beginning of this dialogue, I would be very pleased if you could describe to us how you discovered Orthodoxy.

Rico Vitz: I'm Italian on my father's side, and like many Italian-Americans, I was born into a Roman Catholic family. Despite plenty of my own moral failings and a variety of intellectual misgivings about Roman Catholicism, I have always been drawn toward a devout life. So, when I was a young man, I seriously considered becoming a priest, a Capuchin Franciscan friar, more specifically. During that period of discernment, I met a beautiful woman who was considering becoming a Franciscan missionary. Through much prayer and discernment, we discovered that the vocation to which we were called was marriage, and in 1996, we were married. Almost a decade later, while we were awaiting the birth of our first child, we began to wonder whether we could, in good faith, raise him as a Roman Catholic, given our own growing sense of uneasiness about the faith and practices of Rome. Consequently, we began exploring Protestantism and attending a local Lutheran congregation.

Having been raised as a Roman Catholic, I had always thought of Orthodoxy as something like a corrupted version of Roman Catholicism, for Greeks and Russians. So, having become disillusioned with Rome and being neither Greek nor Russian, Orthodoxy did not really seem like something worth considering. Then something odd happened: one of my colleagues in graduate school converted from Protestantism to Orthodox Christianity. I found this rather puzzling, but it piqued my interest and caused me to consider Orthodoxy on its own merits. That, in short, is the back story of who we are and how we began to be drawn to the Church.

\section{Tudor Petcu: What caused you to convert to Orthodox Christianity?}

Rico Vitz: As we began to explore the faith - first in books, then in person - we were struck by the way that it had maintained a unified conception of truth, beauty, and goodness. This conception of the relationships among truth, beauty, and goodness was taken for granted in the ancient Greco- 
Roman world but has largely been lost by contemporary people, at least in Europe and North America. Now, conversions are complex processes, so obviously we would not have described it in quite these words at the time, but that was in fact what we experienced: Truth. The most faithful expression of the faith once delivered to the saints. Beauty. A sacramental liturgical life of faith that recognizes the created world, especially the Divine Liturgy, as an iconic participation in the uncreated energies of God. Goodness. An ascetic way of life that provides the sacramental instruments for healing body and soul.

In short, we were overwhelmed by the rich experience of life in Christ as a unified conception of truth, beauty, and goodness. It was the experience of that life that lead us to be received into the Holy Orthodox Church on Lazurus Saturday in 2006.

Tudor Petcu: In your opinion, which Orthodox philosophers have managed to highlight the beauty of Orthodoxy in the most relevant ways?

Rico Vitz: There is something profound about the way you have phrased the question. In the western Academy, people do not think much about philosophy in relationship to beauty in the way that you are doing here. (At times now, they barely think of it in relation to truth!) Consequently, I have to think outside of my usual frame of reference to answer your question.

The people whose thought has best illumined the beauty of Orthodoxy for me are the neptic fathers, whose works are collected in the Philokalia, and Dostoevsky. In North America and in much of Europe, there is resistance to calling these figures 'philosophers'. To some extent this is understandable, but to an important extent it is rather myopic and parochial. There are genuine 'philosophers', in the traditional sense of the term (i.e., genuine 'lovers of wisdom'), who fall outside our contemporary frame of reference - e.g., Augustine and Aquinas in the West, Confucius and Xunzi in the Far East. The neptic fathers and Dostoevsky are examples of such lovers of wisdom, lovers of Holy Wisdom, from the Near East and from the Slavic lands.

Tudor Petcu: I would also like to ask you the following question, though I am not quite sure if this is the right way to phrase it. Do you think that it is correct to discuss any orthodox philosophy? I am asking this in light of the fact that many Orthodox confessors, for example those from Russia, were trying to demonstrate that Orthodoxy is not just a philosophy, but is something beyond philosophy, a spiritual wisdom focused on communion with Jesus Christ.

Rico Vitz: The short answer to your question is yes, I do think that it is correct to discuss Orthodox philosophy. So that your readers do not misunderstand my point, let me explain my answer in a bit more detail.

I disagree with the stances taken toward philosophy both by Tertullian and by Origen. Tertullian, on the one hand, claimed that 'Athens' (philosophy) should have little, if anything, to do with 'Jerusalem' (Christianity) and, thus, valued philosophy too lowly. Origen, on the other hand, tried too hard to get Christianity to conform to philosophy and, thus, valued philosophy too highly.

Each of these is a misapplication of the wise counsel St. Paul offers in his epistle to the Colossians, in which he advises us not to be taken captive by vain and deceptive philosophy in accordance with the traditions of men and not in accordance with Christ (Col 2:8). It is important to note two points in order to understand St. Paul's teaching. First, not every engagement with philosophy is an instance of being taken captive by philosophy. Second, not every form of philosophy is both in accordance with the principles of men and not in accordance with Christ. With these points in mind, we can rightly see that St. Paul's teaching is not a prohibition against philosophy per se. Rather, it is 
a prohibition against being taken captive by a certain kind of philosophy, which is 'humanistic' in a way that is opposed to Christ.

In fact, in accordance with the sacred tradition, there are at least four ways that philosophy can be a benefit to Orthodox Christians. First, as St. Clement of Alexandria notes, philosophy can be a preparation for those who are being perfected in Christ. Second, as the lives both of St. Paul and of St. Justin Martyr suggest, philosophy can be a source for apologetic debates (see, e.g., Acts 17:18). Third, as both the theoretical work of the Cappadocian fathers and the practical work of the neptic tradition illustrate, philosophy can be a source of concepts and methods that can be appropriated in new ways to help explain the faith once delivered to the saints (Jude 1:3). Fourth, as the work of St. John Damascene illustrates, these same philosophical tools can be used for the purpose of evangelization.

So, should some forms of philosophizing be avoided? Yes, of course, as sacred scripture and sacred tradition suggest. Does it follow from this that Orthodox Christians should avoid all forms of philosophizing? No, of course not ... also as sacred scripture and sacred tradition suggest.

Tudor Petcu: What could you say about the evolution of Orthodoxy in the US?

Rico Vitz: I have little to say about the more than two-hundred year history of the Orthodox Church in the North America. There are others who would be much more helpful in explaining those details.

I can, however, say a little bit about the more recent evolution of Orthodoxy in the United States. In the past few decades, there has been a significant increase in the number of us Americans, who have found our way home, to the Orthodox Christian Church. We have done so principally with the help of Antioch, via the Antiochian Archdiocese of North America, and of Moscow, via the Orthodox Church in America and the Russian Orthodox Church Outside of Russia. It is these jurisdictions that have probably been most responsive to the deep need for evangelizing the America people.

Tudor Petcu: How can Orthodoxy contribute to the American social identity from a spiritual or cultural point of view?

Rico Vitz: This is a difficult question. Given the times in which we live, it is rather difficult for me to tell exactly what Americans take their social identity to be. This will, of course, be an oversimplification, but essentially, the United States has historically been shaped by classical liberalism and by Protestantism. Now, however, Americans seem en masse to be questioning, if not outright abandoning, these political and religious traditions. Neither of our two major political parties seem deeply committed to classical liberalism, and Protestantism in the United States is in a radical state of upheaval.

I have no idea how things will unfold on either of these fronts. With respect to politics, I worry the United States will largely abandon classical liberalism for some less desirable alternative. With respect to religion, I suspect that much of Protestantism will continue to collapse and that Roman Catholicism will continue to look rather traditional on paper but remain rather syncretistic in practice. So, I suspect that if there is any long-term hope for traditional Christianity in the United States, it will be with the Orthodox Church.

Tudor Petcu: Do you think that there would be any chance in the future for Orthodoxy to become an important part of the American identity? 
Rico Vitz: Yes, but only if we have strong and visionary leadership, especially among our hierarchs. In particular, this will require two things. First, Orthodox Christian jurisdictions in the United States must recognize and present themselves principally as Orthodox Christian, rather than as Greek, Russian, Antiochian, Romanian, and so forth. Thus, they must be faithful to their principal calling to provide a witness for the Gospel. Second, Orthodox Christians must address the intellectual sensibilities of the American people. It is true that the first priority of Orthodox Christians is to draw near to Christ by prayer and ascetic labors. If, however, the Orthodox Church truly wants to become an important part of the American identity, it must find a way of developing and presenting the richness of its intellectual life in such a way that it speaks to the hearts and minds of the American people, who are ignorant of many things that inform the Orthodox life - e.g., Church history, theology, philosophy, patristic psychology, and so forth.

Tudor Petcu: What does being an Orthodox Christian mean for you?

Rico Vitz: I am a sinner, greatly in need of God's mercy. In becoming an Orthodox Christian, I have been adopted into Christ's family, in which I continually encounter the majestic beauty of God's love and experience the sacramental richness of His saving grace. It is here, by God's design that I work out my salvation, supported by the love and prayers of my brothers and sisters in Christ, both those who are living and those who have fallen asleep in the Lord.

Tudor Petcu: How would you describe the relationship of Orthodox Christianity to other Christian spiritualties?

Rico Vitz: In The Orthodox Church, Kallistos Ware presents a parable by Alexis Khomiakov. It goes as follows:

A master departed, leaving his teaching to his three disciples. The eldest faithfully repeated what his master had taught him, changing nothing. Of the other two, one added to the teaching, the other took away from it. At his return the master, without being angry at anyone, said to the two younger, "Thank your eldest brother; without him you would not have preserved the truth which I handed over to you." Then he said to the eldest brother, "Thank your younger brothers; without them you would not have understood the truth which I entrusted to you."

This nicely describes my own experience of the relationship of Orthodox Christianity to Roman Catholicism and Protestantism. The Orthodox Church has provided the most faithful witness to the faith once delivered to the saints. It is here that I have seen the True Light, here that I have received the Heavenly Spirit, and here that I have found the True Faith, worshiping the Undivided Trinity, one in essence and undivided. It was Roman Catholicism and Protestantism, however that helped to lead me here. And there are still many faithful Roman Catholics and Protestants whose lives provide me with encouragement and inspiration, as I strive to work out my salvation.

Does this mean that I believe that the Orthodox Christian Church, Roman Catholicism, and Protestantism are simply equal and interchangeable ways of trying to commit one's life to Christ? No, it does not. Do I hope that my Roman Catholic and Protestant family and friends will become Orthodox? Yes, I do, in God's time.

Tudor Petcu: Should we say that it is only in the Orthodox Church that people can gain redemption?

Rico Vitz: The Orthodox Christian Church is the spiritual hospital founded by Jesus Christ. Thus, it possesses the fullness of the means of grace by which God aims to save every person, body and 
soul. Does that mean that the Holy Spirit is inactive outside the Orthodox Church? No, clearly not; otherwise, no one would convert to the faith. Does it mean that every person who dies without having been baptized into the Orthodox Church will be eternally separated from God? I don't know. God knows. Given all that I have studied and experienced, however, I seriously doubt that is the case.

Tudor Petcu: Given the subject of our dialogue, I think it would be very good if we would make reference to your philosophical work Turning East which is so important for a right understanding of Orthodox Christianity defined in its own history. What is the main purpose of this work?

Rico Vitz: In case some of your readers might not be familiar with the book, let me say a bit about both how it came together and what we hoped to accomplish.

I tend to be rather intrigued by people and their stories. After I converted to Orthodoxy, I began meeting other philosophers who had also converted. So, naturally, I would ask them how they came to Orthodoxy, and I found each of their answers fascinating. One day, I asked a couple of these Orthodox philosophers what they thought of the idea of a book, featuring a collection of these kinds of conversion stories. They loved the idea and encouraged me to put such a book together. That was the beginning of the project that became Turning East: Contemporary Philosophers and the Ancient Christian Faith.

In putting the text together, our purpose was twofold. First, we wanted to introduce Orthodox Christianity to Westerners who had at least a passing interest in philosophy. Second, we wanted to help encourage them to inquire into the faith. Judging from the responses we have received, the book seems to be doing well on both those points. But it also seems to be having a third effect, which we did not foresee - namely, drawing the interest of people in Orthodox countries and helping them to see their own faith in fresh ways. Because of this the book is now being translated into Greek and may be translated into Russian. I have also recently learned that a Romanian translation, Intoarcerea spre Răsărit, is supposed to be forthcoming this year from Renaşterea. 